\title{
Rancang Bangun Aplikasi Pemesanan Tiket Shuttle Bus Berbasis Android pada Putra KJU Karawaci Banten Indonesia
}

\author{
Henny Yulianti \\ Program Studi Teknik Informatika \\ Fakultas Sains dan Teknologi \\ Universitas Pramita Indonesia \\ Jl. Boulevard Taman Ubud Lippo Karawaci ,Tangerang- Banten 15810 \\ hyulia.999@gmail.com
}

Diterima: 15 November 2020. Disetujui: 8 Desember 2020. Dipublikasikan: 8 Desember 2020.

\begin{abstract}
Putra KJU is a company engaged in shuttle bus transportation services, where ticket reservations, departure schedule information, and payment transactions are still manual, namely going directly to ticket sales counters, which is one of the problems is when the afternoon and morning rush hours often occur queues at ticket sales counters, so that prospective passengers do not get good service from officers. Along with the increasingly rapid development of technology where everything is done by mobile, it is necessary to apply technology to the company to make it easier for prospective passengers to get purchase services and access shuttle departure schedule information, companies can also manage ticket sales more quickly and easily. Because of that then the author took the initiative to create an application about ordering shuttle bus tickets with an Android Studio-based system which is integrated with the CodeIgniter Framework in mobile. The application consists of a web-based admin and a mobile android user. In this study using the UML (Unified Modeling Language) model method. And in testing, it was carried out by the Black box method which went well then with Alpha testing with an average total score of 39 and a presentation of success of $88.2 \%$ and Beta testing with an average total score of 123.3 with a percentage of success of $91.3 \%$. So, the shuttle bus ticket booking application system is feasible to use to help provide an efficient and comfortable public transportation system.
\end{abstract}

Keywords: android studio, internet, shuttle bus, mobile, uml.

Abstrak--Putra KJU merupakan perusahaan yang bergerak dalam bidang jasa trasnportasi shuttle bus, dimana pemesanan tiket, informasi jadwal keberangkatan, dan transaksi pembayaran masih bersifat manual yakni mendatangi langsung loket penjualan tiket, yang menjadi salah satu permasalahannya adalah ketika jam sibuk sore dan pagi sering terjadi antrian di loket penjualan tiket, sehingga calon penumpang kurang mendapat pelayanan yang baik dari petugas. Seiring dengan perkembangan teknologi yang semakin pesat dimana segala sesuatu dilakukan secara mobile maka perlu adanya penerapan teknologi pada perusahaan guna mempermudah calon penumpang untuk mendapatkan pelayanan pembelian dan mengakses informasi jadwal keberangkatan Shuttle, perusahaan pun dapat mengelola penjualan tiket dengan lebih cepat dan mudah. Karena hal itu maka penulis berinisiatif untuk membuat suatu Aplikasi tentang Pemesanan Tiket Shuttle Bus dengan sistem berbasis Android yang di integrasikan dengan Framework CodeIgniter secara mobile. Aplikasi terdiri dari admin berbasis web dan pengguna (user) yang berbasis android. Dalam penelitian ini menggunakan metode model UML (Unified Modelling Language). Dan pengujian, dilakukan dengan metode Black box berjalan baik lalu dengan pengujian alfa dengan hasil skor total rata-rata 39 dan presentasi keberhasilan $88,2 \%$ dan pengujian beta dengan skor total rata-rata 123,3 dengan presentasi keberhasilan 91,3\%. Maka sistem aplikasi pemesanan tiket shuttle bus ini layak digunakan untuk memebantu sistem transportasi masyarakat yang efisiensi dan nyaman.

Kata kunci: android studio, internet, shuttle bus, mobile, uml.

\section{PENDAHULUAN}

Perkembangan Teknologi Informasi pada saat ini khusus nya pada penggunaan informasi menggunakan teknologi smartphone (telepon pintar) yang sudah semakin canggih. Hampir semua fitur yang dimiliki komputer mampu dilakukan oleh teknologi smartphone. Sejalan dengan hal tersebut tuntutan dan kebutuhan masyarakat akan pelayanan yang berkualitas dan praktis semakin dibutuhkan.
Karena dapat memudahkan dan menghemat waktu di tengah kesibukan yang semakin padat. Salah satu contoh dari pemanfaatan teknologi yang dapat memudahkan masyarakat dalam melakukan perjalanan yaitu dibidang bisnis travel yang pada saat ini sangat pesat dan sangat diminati oleh masyarakat yang membutuhkan kemudahaan dan efisiensi waktu dalam mencapai tempat tujuan.

Internet adalah sebuah teknologi yang bisa memberikan informasi pendahuluan yang perlu 
diketahui sebagai pengantar dunia internet. Internet awalnya digunakan untuk keperluan militer hingga akhirnya menjadi massal untuk keperluan sipil dan hiburan [1]. Sebelum adanya internet penumpang harus datang ke agen untuk memesan tiket, tidak jarang juga penumpang dibuat kecewa karena tiket yang dipesan telah habis. Putra KJU merupakan salah satu perusahaan penyedia layanan transportasi yang sangat berkembang dan belum memanfaatkan teknologi internet sebagai sarana pengembangan layanan kepada penumpang. Hal ini sering menjadi permasalahan karena penumpang tidak dapat memesan tiket tanpa harus ke loket travel, dan melihat jadwal serta jumlah tiket yang tersisa secara langsung dan perusahaan tidak dapat meng informasikan secara langsung kepada penumpang.

Untuk itu perlu adanya proses pemesanan tiket travel untuk lebih mengefisienkan baik dari segi waktu catatan data penumpang maupun biaya serta lebih memudahkan, lebih cepat dan lebih praktis tentunya dalam melakukan pemesanan tiket adalah dengan menggunakan internet dan smartphone [2].

Berdasarkan masalah tersebut penulis tertarik untuk membangun sistem informasi berbasis android studio [3] dengan di integrasikan sistem framework code igniter [4] guna memudahkan dalam hal mengakses informasi yang berhubungan dengan Putra KJU baik profil maupun layanan melalui teknologi internet sehingga dapat menciptakan efektifitas dan efisiensi dalam hal pemasaran dan pelayanan perusahaan Putra KJU kepada pelanggan dan masyarakat.

Untuk melihat kelebihan aplikasi pemesanan tiket yang akan di rancang dan dikembangkan penulis, berikut beberapa penelitian sejenis yaitu, membahas tentang pengembangan sistem tiket bus dengan berbasis website [5] dengan membuat sistem pemesanan tiket berbasis website sehingga penumpang travel bisa melihat jadwal dan jumlah tiket yang tersisa.

Penelitian [6] telah membangun aplikasi dengan menggunakan sistem scan $Q R$ code saat akan keberangkatan bus untuk menghindari jumlah antrian yang menumpuk. Lalu penelitian tentang pemesanan tiket [7] adalah merancang aplikasi pemesanan tiket antar kota dengan berbasis android dan [8] aplikasi rute bus dengan smartphone android.

Dari keempat penelitian sebelumnya, maka berikut ini akan dijelaskan hal-hal yang membedakan aplikasi yang akan dibangun penulis dengan aplikasi yang telah dibangun sebelumnya. Aplikasi pemesanan tiket shuttle ini dengan mengimplementasikan teknologi Android Studio dengan platform mobile yang di integrasikan dengan framework CodeIgniter.

Teknologi Android Studio yang compatible dengan sistem mobile [9]-[11] maka nantinya aplikasi pemesanan tiket ini para calon penumpang bisa langsung memesan tiket dari mana saja dengan smartphone-nya dan juga bisa membaca informasi jadwal, jumlah tiket yang tersisa dan lokasi tujuan mana yang dituju. Sehingga hal ini sangat membantu aktifitas pelanggan dan pengguna menjadi lebih efektif dan efisiensi dalam waktu mereka

Para penumpang juga bisa langsung memesan tempat duduk (booking) dengan langsung dari smartphone mereka. Hal ini bisa langsung mengatasi permasalahan menumpuk penumpang ketika saat keberangkatan karena para penumpang sudah jelas (fixed) tempat duduk di bus, jam keberangkatan, dari mana keberangkatan dan tujuan penumpang serta biaya operasional di perusahaan shuttle bus juga jadi lebih murah. Maka hal ini juga akan membuat praktis dan murah biaya operasional perusahaan travel dalam mengelola perusahaan transportasi. Sehingga diharapkan nantinya mampu memenuhi kebutuhan penumpang (user) dengan baik dan membuat pengguna nyaman dalam perjalanannya.

Berdasarkan hal tersebut dapat disimpulkan permasalahan dan cara untuk mengatasinya, maka penulis akan membangun aplikasi berbasis android studio dengan platform mobile yang di integrasikan framework CodeIgniter dengan Judul "Rancang Bangun Aplikasi Pemesanan Tiket berbasis Android pada Putra KJU -Karawaci Banten" yang dapat memberikan kemudahan dan kenyamanan dalam pemesanan tiket shuttle bus bagi masyarakat di daerah Karawaci dan sekitarnya serta di Propinsi Banten pada khususnya.

\section{TINJAUAN PUSTAKA}

Penelitian ini dibuat berdasarkan dari sumber referensi yang telah ada, terutama dari segi teori yang digunakan, berikut beberapa teori yang digunakan beserta referensi ahlinya.

\section{A. Android}

Android adalah sebuah sistem operasi untuk perangka mobile berbasis Linux yang mencakup sistem operasi, middleware dan aplikasi. Android menyediakan platform terbuka bagi para pengembang untuk membuat aplikasi mereka. Awalnya, Google Inc. membeli Android Inc yang merupakan pendatang baru yang membuat software untuk smartphone. Lalu untuk mengembangkan android, dibentuklah Open Handset Alliance, konsorsium dari 34 perusahaan hardware, software, 
dan telekomunikasi, termasuk Google, HTC, Intel, Motorola, Qualcomm, T Mobile, dan Nvidia [10].

\section{B. Android Studio}

Android studio adalah Integrated Development Environment (IDE) untuk sistem operasi Android, yang dibangun di atas perangkat lunak JetBrains IntelliJ IDEA dan di desain khusus untuk pengembangan android. Android studio dibangun dengan tujuan mempercepat proses pembuatan maupun pengembangan aplikasi android yang berkualitas tinggi untuk setiap device android. [9]-[11]-[12]

\section{Shuttle Bus}

Shuttle bus adalah sistem transportasi menggunakan bus secara point to point dari suatu tempat ke tempat lain, hanya memberangkatkan dan menurunkan penumpang di tempat tertentu. Dan shuttle bus, angkutan umum yang melayani penumpang dengan cara melayani dari suatu asaltujuan tertentu tanpa perhentian yang berarti di antara keduanya [13].

\section{Mobile}

Mobile yang dimaksud adalah aplikasi yang dirancang khusus untuk platform mobile (misalnya iOS, android, windows mobile). Aplikasi mobile memiliki user interface dengan mekanisme interaksi unik yang disediakan oleh platform mobile, interoperabilitas dengan sumber daya berbasis web yang menyediakan akses ke beragam informasi yang relevan dengan aplikasi dan kemampuan pemrosesan lokal untuk pengumpulan, analisis dan format informasi dengan cara yang paling cocok untuk platform mobile. Selain itu aplikasi mobile menyediakan kemampuan penyimpanan persisten dalam platform [9].

\section{E. Framework}

Framework adalah suatu struktur konseptual dasar yang digunakan untuk memecahkan atau menangani suatu masalah kompleks. Istilah ini sering digunakan antara lain dalam bidang perangkat lunak untuk menggambarkan suatu desain sistem perangkat lunak yang dapat digunakan kembali, serta dalam bidang manajemen untuk menggambarkan suatu konsep yang memungkinkan penanganan berbagai jenis atau entitas bisnis secara homogen. [14].

\section{F. CodeIgniter}

CodeIgniter memiliki banyak fitur yang membantu para pengembang PHP untuk dapat membuat aplikasi web secara mudah dan cepat. CodeIgniter mengizinkan para pengembang untuk menggunakan framework secara parsial maupun secara keseluruhan [15].

\section{G. Alur Penelitian}

Dalam penelitian menggunakan metode penelitian Model Waterfall, Metode Model Waterfall mencerminkan kepraktisan rekayasa, yang bisa membuat kualitas perangkat lunak tetap terjaga. Dan dalam pengerjaan dari suatu sistem yang dilakukan secara berurutan atau liniear. Metode ini juga bersifat lengkap sehingga proses pemeliharaannya lebih mudah [16].

Proses dari Metode Model Waterfall di jelaskan pada Gambar 1.

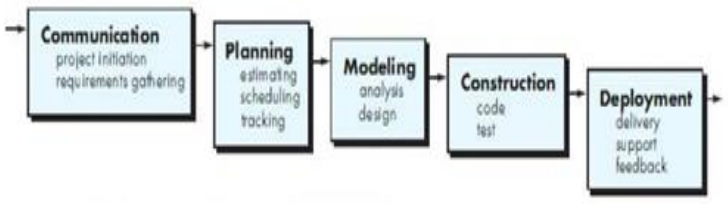

Gambar 1. Waterfall Pressman (Pressman, 2015:42) [16]

\section{Communication}

Langkah ini merupakan analisis terhadap kebutuhan perangkat lunak, dan tahap untuk mengadakan pengumpulan data dengan melakukan pertemuan dengan objek penelitian, maupun mengumpulkan data-data tambahan baik yang ada di jurnal, artikel, maupun dari internet.

2. Planning

Proses planning merupakan lanjutan dari proses communication (analysis requirement). Tahapan ini akan menghasilkan dokumen perencanaan proses pengembangan perangkat lunak atau bisa dikatakan sebagai data yang berhubungan dengan proses pengerjaan.

3. Modelling

Proses modeling ini akan menerjemahkan syarat kebutuhan ke sebuah perancangan perangkat lunak yang dapat diperkirakan sebelum dilakukan pengkodean perangkat lunak. Proses ini berfokus pada rancangan struktur data, arsitektur perangkat lunak, representasi interface, dan detail (algoritma) prosedural.

4. Construction

Construction merupakan proses membuat coding atau pengkodean merupakan penerjemahan desain dalam bahasa yang bisa dikenali oleh komputer. Programmer akan menerjemahkan kebutuhan ke dalam bentuk antarmuka perangkat lunak melalui pengkodean. Tahapan inilah yang merupakan tahapan secara nyata dalam mengerjakan suatu perangkat lunak, artinya penggunaan komputer akan dimaksimalkan dalam tahapan ini. Setelah 
pengkodean selesai maka akan dilakukan pengujian terhadap sistem yang telah dibuat. Tujuan pengujian adalah menemukan kesalahan- kesalahan terhadap perangkat lunak untuk kemudian bisa diperbaiki.

\section{Deployment}

Tahapan ini bisa dikatakan final dalam pembuatan sebuah perangkat lunak. Setelah melakukan analisis, desain dan pengkodean maka sistem yang sudah jadi akan digunakan oleh user. Kemudian perangkat lunak yang telah dibuat harus dilakukan pemeliharaan secara berkala.

\section{H. Metode Pengembangan Perangkat Lunak (UML)}

Dalam merancang perangkat lunak, penulis menggunakan pemodelan UML (Unified Modeling Language). Rancang bangun sebuah sistem perangkat lunak, mengatur kompleksitas adalah salah satu alasan utama mengapa harus membuat model, pemodelan membantu para pengembang untuk dapat fokus, dapat mendokumentasikan, menangkap keseluruhan sistem dan mengkomunikasikan aspek-aspek penting dalam sistem yang sedang dirancang [17].

Untuk merancang perangkat lunak, penulis menggunakan 4 diagram yang ada pada UML, yakni Use case diagram, Activity diagram, Sequence diagram dan Class diagram.

\section{RANCANGAN \& PENELITIAN}

\section{A. Penelitian}

Dalam penelitian ini penulis menggunakan metode penelitian deskriptif dan tindakan (action research). Penelitian deskriptif merupakan penelitian yang dimaksudkan untuk mengumpulkan informasi mengenai status suatu gejala yang ada, yaitu keadaan gejala menurut apa adanya pada saat penelitian dilakukan. Sedangkan metode tindakan (action research) yaitu penelitian yang digunakan untuk mengembangkan keterampilan-keterampilan baru, cara pendekatam baru, atau produk pengetahuan yang baru dan untuk memecahkan masalah dengan penerapan langsung di dunia aktual /lapangan.

Metode penelitian yang digunakan penulis adalah metode model Waterfall karena metode ini melakukan pendekatan secara sistematis dan berurutan. Disebut dengan waterfall karena tahap demi tahap yang dilalui harus menunggu selesainya tahap sebelumnya dan berjalan berurutan. Metode penelitian model Waterfall dapat dijelaskan sebagai berikut [12] :

\section{Communication.}

Tahapan pertama yakni penulis mencari kebutuhan software yang akan dibuat, dengan mengumpulkan data dan informasi pada tempat penelitian yakni di Putra KJU. Proses ini dilakukan dengan beberapa tahapan sebagai berikut:

a. Pengamatan dilakukan ditempat penelitan melihat bagaimana sistem di sana berjalan khususnya pada bagian penjualan tiket.

b. Wawancara dilakukan dengan petugas loket dan beberapa petugas staff karyawan Putra KJU. Hal ini dilakukan untuk memahami dan mencapai tujuan yang ingin dicapai dari pembuatan aplikasi pemesanan tiket ini.

c. Penulis mencari berbagai teori dari berbagai sumber untuk menunjang kebutuhan software yang akan rancang. Dan juga mengumpulkan data-data yang diperlukan dari jurnal, artikel dan internet.

d. Dan menganalisis permasalahan yang dihadapi dengan data-data yang terkumpulkan, serta membantu mendefinisikan fitur dan fungsi software yang sesuai keinginan pemesan (user) pemakai shuttle bus di daerah Karawaci dan sekitarnya.

\section{Planning (Estimating, Scheduling,Tracking)}

Tahap berikutnya tahapan perencanaan yang menjelaskan tentang estimasi hal-hal teknis yang akan dibuat dalam aplikasi pemesanan tiket shuttle bus ini, resiko-resiko yang dapat terjadi ketika nanti applikasi pemesanan tiket ini diimplementasikan, sumber daya yang diperlukan dalam membuat sistem aplikasi pemesanan tiket shuttle bus ini, hasil akhir aplikasi yang ingin dihasilkan, penjadwalan dalam pembuatan aplikasi pemesanan tiket yang akan dilaksanakan, dan tracking proses pengerjaan sistem applikasi tersebut.

\section{Modelling (Analysis \& Design).}

Tahapan ini adalah tahapan perancangan dan permodelan arsitektur sistem yang berfokus pada perancangan struktur data, arsitektur software, tampilan interface, dan algoritma program. Tujuannya untuk lebih memahami gambaran besar dari apa yang akan dikerjakan dalam perancangan applikasi pemesanan tiket shuttle bus di Putra KJU.

\section{Construction}

Tahapan construction ini merupakan proses penerjemahan bentuk desain menjadi kode atau bentuk/bahasa yang dapat dibaca oleh mesin. Setelah pengkodean selesai, dilakukan pengujian terhadap sistem dan juga kode yang sudah dibuat. Tujuannya untuk menemukan kesalahan yang mungkin terjadi untuk nantinya diperbaiki.

\section{Deployment.}

Tahapan deployment merupakan tahapan implementasi software ke customer, pemeliharaan 
software secara berkala, perbaikan software, evaluasi software, dan pengembangan software berdasarkan umpan balik yang diberikan agar sistem dapat tetap berjalan dan berkembang sesuai dengan fungsinya.

\section{B. Perancangan (Design)}

Dalam membuat atau merancang perangkat lunak applikasi pemesanan tiket shuttle bus ini penulis menggunakan metode model UML yang terdiri dari 4 diagram yang ada pada UML, yakni Use case diagram, Activity diagram, Sequence diagram dan Class diagram.

\section{Use Case Diagram.}

Penelitian ini pemodelan yang akan digunakan dalam menggambarkan kebutuhan fungsional pada perangkat lunak yang dibangun yaitu dengan pemodelan use case diagram.Use case diagram dibagi menjadi 2 yaitu pengguna (user) dan admin yang digambarkan pada Gambar 2 dan Gambar 3.

a. Use case diagram untuk pengguna (user)

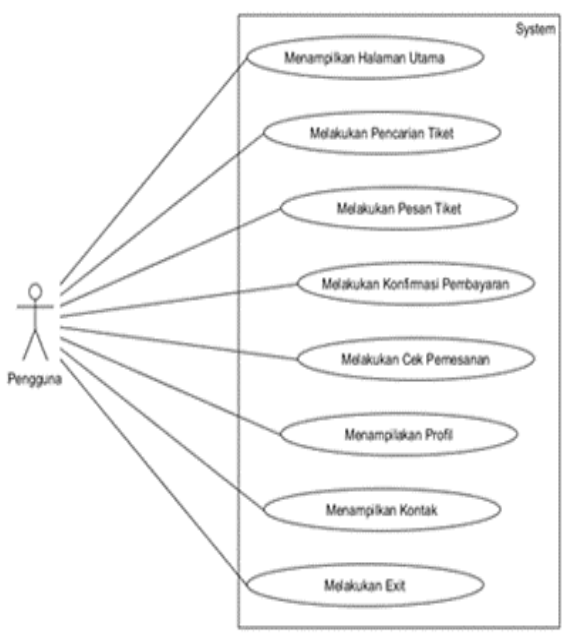

Gambar 2. Use Case Diagram User

Berdasarkan use case diagram untuk user pada Gambar 2, dapat di definisikan interaksi yang terjadi pada applikasi sebagai berikut:

\section{TABEL I. INTERAKSI TERJADI USE CASE DIAGRAM PENGGUNA}

\begin{tabular}{|c|l|}
\hline No & Interaksi Yang Terjadi \\
\hline 1 & Menampilkan halaman utama \\
\hline 2 & Melakukan Pencarian Tiket \\
\hline 3 & Melakukan Pesan Tiket \\
\hline 4 & Melakukan konfirmasi pembayaran \\
\hline 5 & Melakukan Cek pemesanan \\
\hline 6 & Menampilkan Profile \\
\hline 7 & Menampilkan Kontak \\
\hline 8 & Melakukan Exit \\
\hline
\end{tabular}

b. Use case diagram administrator (admin)

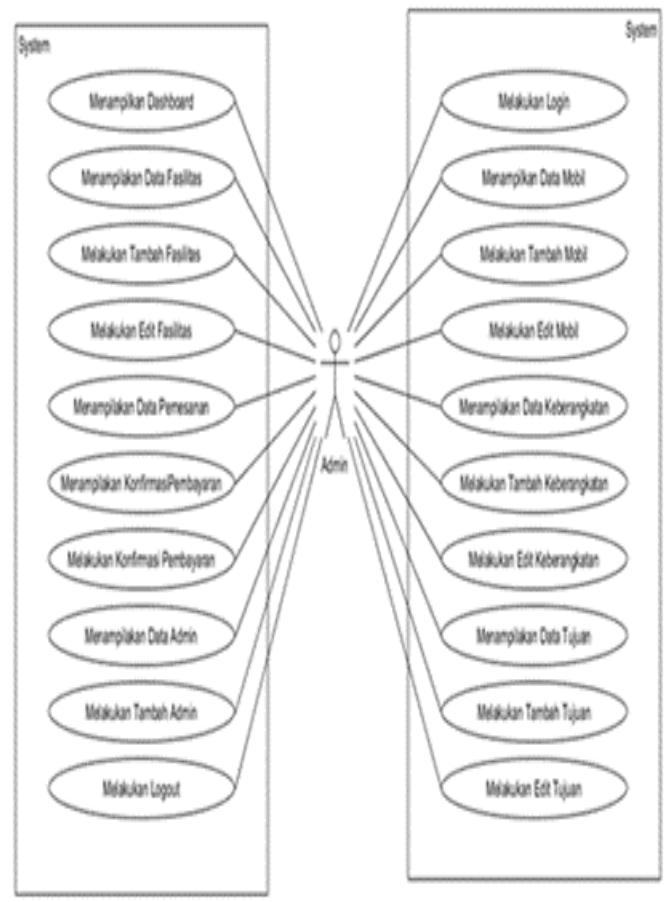

Gambar 3. Use Case Diagram Administrator

Berdasarkan use case diagram administrator pada Gambar 3 dapat didefinisikan interaksi yang terjadi pada aplikasi sebagai berikut:

TABEL II. INTERAKSI TERJADI PADA USE CASE DIAGRAM ADMINSTRATOR

\begin{tabular}{|c|l|}
\hline No & Interaksi Yang Terjadi \\
\hline 1 & Melakukan login \\
\hline 2 & Menampilkan data mobil \\
\hline 3 & Melakukan tambah mobil \\
\hline 4 & Melakukan edit mobil \\
\hline 5 & Menampilkan data keberangkatan \\
\hline 6 & Melakukan tambah keberangkatan \\
\hline 7 & Melakukan edit keberangkatan \\
\hline 8 & Menampilkan data tujuan \\
\hline 9 & Melakukan tambah tujuan \\
\hline 10 & Melakukan edit tujuan \\
\hline 11 & Menampilkan dashboard \\
\hline 12 & Menampilkan data fasilitas \\
\hline 13 & Melakukan tambah fasilitas \\
\hline 14 & Melakukan edit fasilitas \\
\hline 15 & Menampilkan data pemesanan \\
\hline 16 & Menampilkan konfirmasi pembayaran \\
\hline 17 & Melakukan konfirmasi pembayaran \\
\hline 18 & Menampilkan data admin \\
\hline 19 & Melakukan tambah admin \\
\hline 20 & Melakukan logout \\
\hline
\end{tabular}




\section{Activity Diagram}

Activity diagram menggambarkan rangkaian aliran dari aktivitas, digunakan untuk mendeskripsikan aktivitas yang dibentuk dalam satu operasi sehingga dapat juga untuk aktivitas lainnya, pada aplikasi pemesanan tiket shuttle bus Perusahaan Putra Karya Jasa Usaha terdapat 5 aktivitas diagram yaitu sebagai berikut:

\section{a. Activity Diagram Pesan Tiket}

Gambar 4 merupakan awal dari activity diagram dimulai dengan mengaktifkan koneksi internet, karena aplikasi Android ini bekerja secara online. Kemudian pengguna (user) membuka aplikasi shuttle Putra KJU. Pada menu pencarian tiket pengguna memasukan tempat keberangkatan, tujuan dan tanggal. Dan system menampilkan jadwal shuttle bus dan jam keberangkatan sesuai tujuan dan tanggal yang pengguna inginkan.

Kemudian pengguna (user) memilih jam keberangkatan dan mengisi data penumpang seperti nama, nomor ponsel, email dan lainnya sesuai form yang disediakan aplikasi. Berikutnya pemesan (user) mengkonfirmasi pesanan. Selanjutnya sistem merekam data yang telah pengguna input dan mengirimkan invoice tagihan pembayaran tiket secara otomatis ke email yang telah pengguna masukkan. Selanjutnya pengguna (user) membayar tagihan sesuai invoice yang dikirim melalui email. Selanjutnya pengguna mengkonfirmasi pembayaran dengan mengisi form konfirmasi pembayaran. Kemudian konfirmasi pembayaran di terima sistem dan tiket berhasil dipesan. Setelah tiket berhasil dipesan maka selesailah tahap ini.

\section{b. Activity Diagram Cek Pemesanan}

Pengguna (user) memilih menu cek pemesanan. Kemudian sistem menampilkan form pemesanan. Lalu pengguna meng-input alamat email, nomor telepon, kode booking dan submit. Selanjutnya sistem menampilkan data pemesan tersebut.

c. Activity Diagram Konfirmasi Pembayaran

Pada Gambar 6 pengguna memilih menu konfirmasi pembayaran. Selanjutnya, sistem menampilkan form konfirmasi pembayaran. Berikutnya pengguna mengisi form konfirmasi pembayaran dengan mengisi data seperti kode booking, nomor rekening, jumlah transfer. Lalu sistem menyimpan data konfirmasi pembayaran penumpang tersebut.

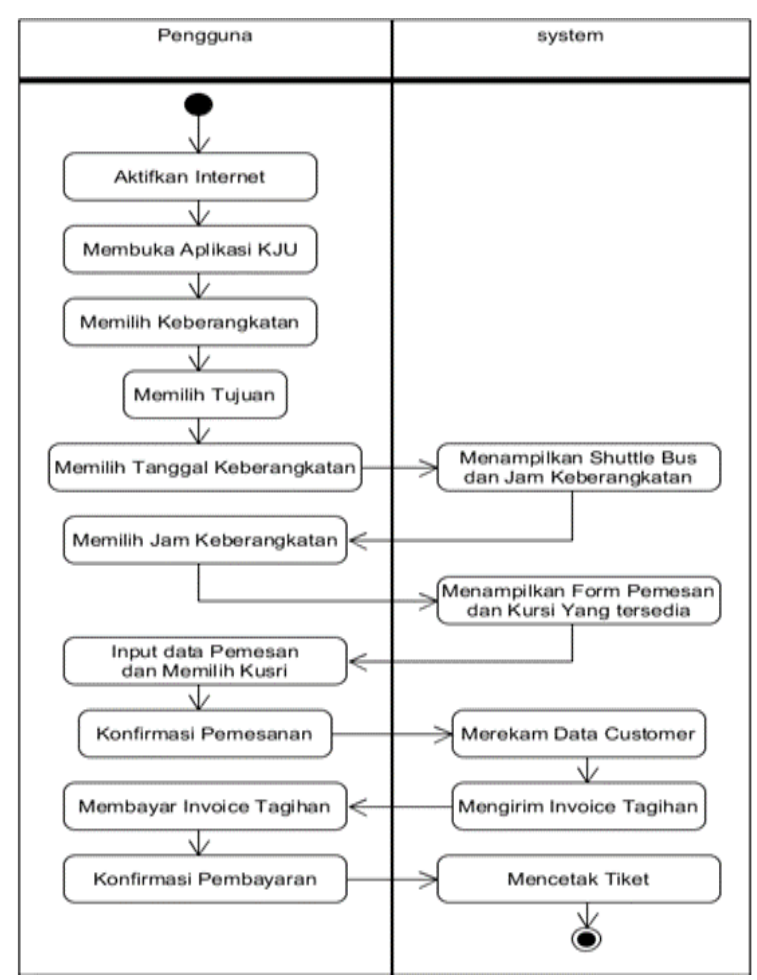

Gambar 4. Activity Diagram Pesan Tiket

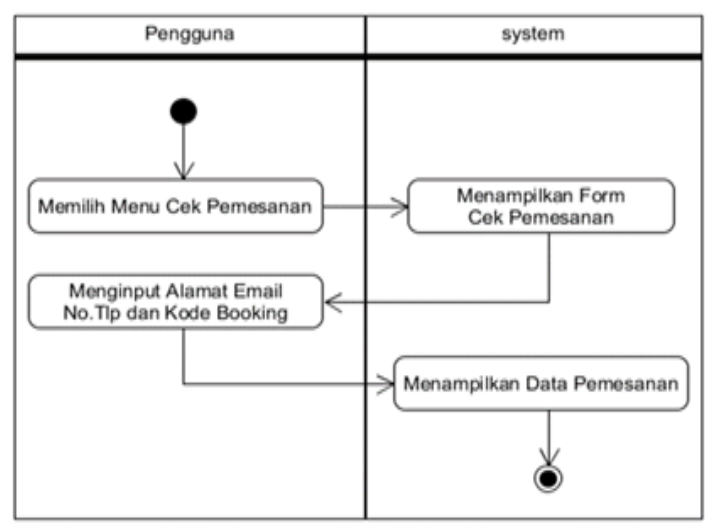

Gambar 5. Activity Diagram Cek Pemesanan

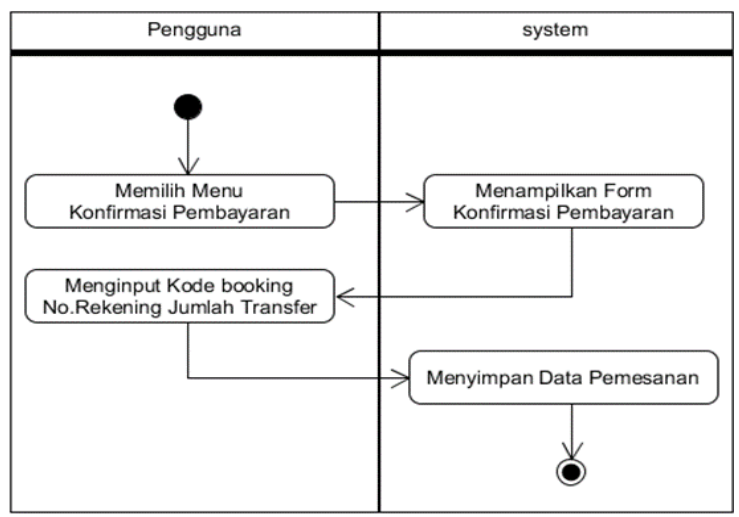

Gambar 6. Activity Diagaram Konfirmasi Pembayaran 


\section{d. Activity Diagram Menu Hubungi}

Pada Gambar 7, Awalnya pengguna (user) memilih menu hubungi. Selanjutnya sistem menampilkan menu hubungi yang berisikan kontak perusahaan yang bisa dihubungi setelah menghubungi maka selesai.

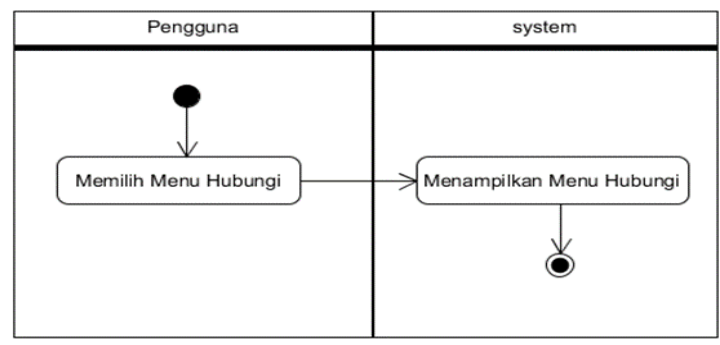

Gambar 7. Activity Diagram Menu Hubungi

\section{e. Activity Diagram Menu Profil}

Pada Gambar 8, sesuai dengan diagram activity diatas, di mulai dengan pengguna memilih menu profil Lalu sistem menampilkan menu profil yang berisikan profil dari perusahaan Putra KJU. Setelah dilakukan proses ini maka selesai tahapan ini.

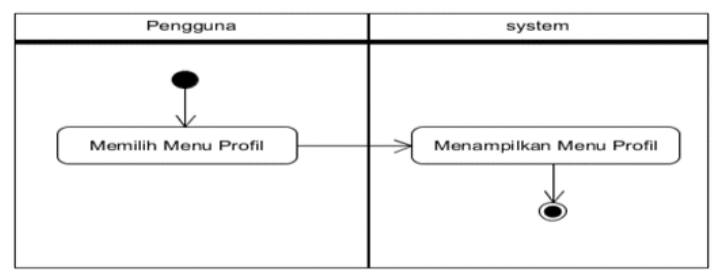

Gambar 8. Activity Diagram Men4u Profil

\section{Sequence Diagram}

Sequence diagram digunakan untuk menggambarkan skenario atau rangkaian langkahlangkah yang dilakukan sebagai respon dari sebuah event untuk menghasilkan output tertentu, diagram ini menunjukan sejumlah contoh objek dan message yang diletakan diantara objek-objek di dalam use case, pada aplikasi pemesanan tiket shuttle bus ini terdapat dua sequnce diagram sebagai berikut:

\section{a. Sequence diagram pemesanan tiket}

Pada Gambar 9 tahap awal diagram sequence ini, dimulai dengan pengguna (user) meng-input data pemesanan. Selanjutnya maka sistem akan menampilkan form pemesanan, menampilkan data pemesanan, dan menyimpan data pemesanan tersebut. Lalu administrator (admin) akan mencek data pemesanan, mengubah status pembayaran dan meng-update data pemesananan.

b. Sequence diagram pembuatan jadwal keberangkatan
Pada Gambar 10 tahap berikutnya dari diagram sequence adalah administrator (admin) akan memilih bus shuttle yang ditentukan dengan kode bus, lalu admin akan memilih keberangkatannya dan tujuan. Dan administrator juga akan. memilih tanggal dan jam keberangkatannya. Terakhir admin akan meng-input harga dari tiket bus pemesan tersebut.

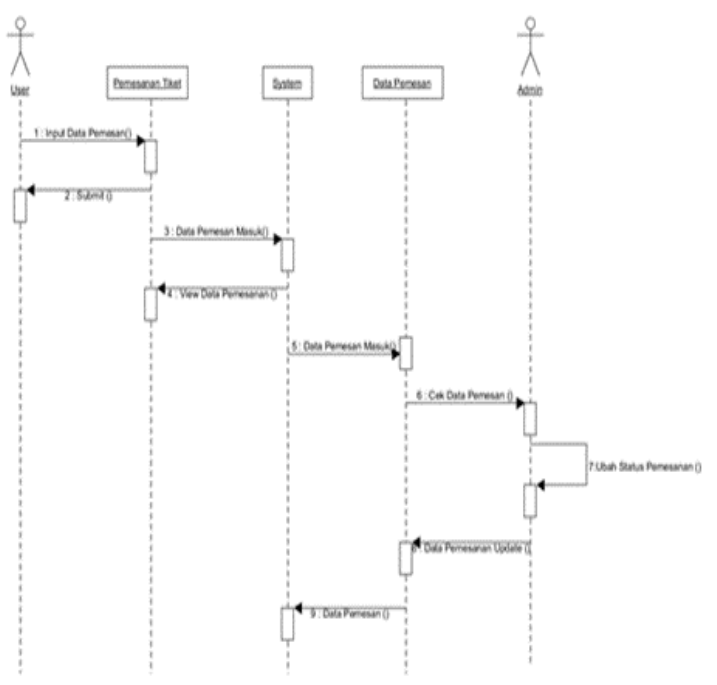

Gambar 9. Sequence Diagram Pemesanan Tiket

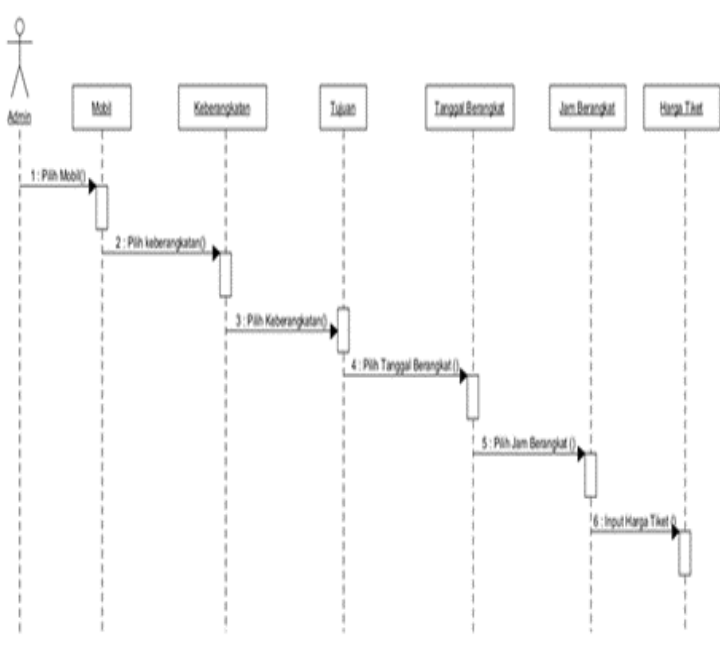

Gambar 10. Sequence Diagram Pembuatan Jadwal Keberangkatan

\section{Class Diagram}

Class diagram merepsentasikan sesuatu yang ditangani oleh sistem, dengan melihat karakteristik sistem pemesanan tiket mulai dari bagian pendaftaran sampai dengan pemesanan beserta proses-proses yang terjadi, semua itu dibuat di dalam class diagram. Gambar 11 berikut ini, menggambarkan struktur statis class di dalam sistem aplikasi pemesanan tiket ini. 


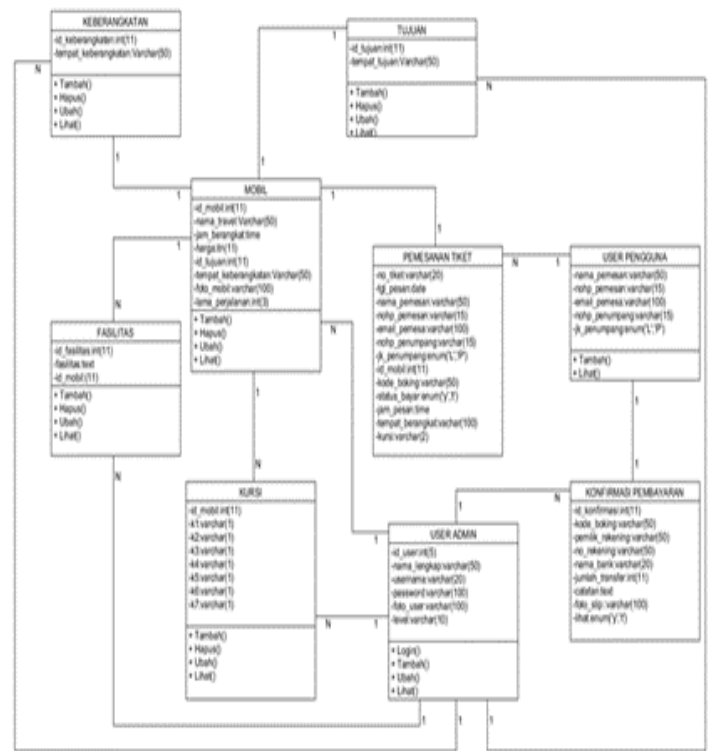

Gambar 11. Class Diagram

\section{Pengujian}

Tahap pengujian ini dilakukan untuk mengetahui kekurangan dan tingkat kepuasan bagi yang menggunakan aplikasi pemesanan tiket shuttle bus ini dan juga memperbaiki aplikasi agar pengguna nyaman dalam menggunakannya. Untuk melakukan pengujian, digunakan beberapa metode pengujian yaitu pengujian Black Box, pengujian Alpha dan pengujian Beta dari hasil implementasi aplikasi ini kepada beberapa responden dengan mengisi kuesioner:

\section{Pengujian Black Box}

Pada tahap pengujian Black box terhadap aplikasi pemesanan tiket online ini pengujian dilakukan dengan menjalankan semua fungsi dan fitur yang ada dari aplikasi ini dan kemudian dilihat apakah hasil dari fungsi-fungsi tersebut sesuai dengan yang diharapkan, aplikasi dijalankan melalui suatu operating system android untuk user customer dan web browser untuk user admin [18].

\section{Pengujian Alpha}

Pengujian alpha ini dilakukan oleh pembuat sendiri dengan menguji tampilan (interface), menu, fungsi tombol, gambar, teks dan audio yang dihasilkan dari aplikasi yang di-testing ataupun diujikan [19]

3. Pengujian Beta

Pada pengujian ini dilakukan dengan cara memberikan tes kuesioner yaitu menjawab kuesioner sesudah menggunakan aplikasi pemesanan tiket shuttle bus. Pengujian ini digunakan untuk mengetahui sejauh mana aplikasi ini berfungsi dengan baik. Pengujian Beta merupakan pengujian yang dilakukan langsung oleh pengguna (user) [20].

\section{Kuesioner \& Teknik Analisis Data Kuesioner}

1. Kuesioner

Penelitian ini mengambil sampel sebanyak 9 orang responden ahli (Alfa) dan 27 orang responden (Beta) yang berumur 17-30 tahun yang rata-rata dalam sebulan menggunakan jasa transportasi bus sebanyak 1-4 kali. Responden berasal dari berbagai kalangan seperti guru, mahasiswa, siswa, karyawan dan swasta sekitar Karawaci. Kuesioner yang dilakukan dengan memberikan beberapa pertanyaan mengenai aplikasi pemesanan tiket dengan teknologi mobile yang dipakai, segi informasi yang disampaikan dan tampilan applikasi android.

Untuk dapat menyimpulkan data yang diperoleh dari hasil kuesioner yang telah diisi, diperlukan perhitungan dengan rumus tertentu agar didapatkan persentase dari setiap jawaban responden. Dalam hal ini, penulis menggunakan persamaan sebagai acuannya. Di bawah ini merupakan Skala Likert yang digunakan dalam perhitungan.

\section{Teknik Analisa Kuesioner}

Skala Likert merupakan sebuah skala untuk mengukur sikap, pendapat dan persepsi seseorang atau sekelompok orang tentang kejadian atau gejala. Dengan menggunakan Skala Likert, variabel yang diukur dijabarkan menjadi indikator variabel yang dapat diukur. Kemudian indikator tersebut dijadikan sebagai titik tolak ukur untuk menyusun item-item instrumen yang dapat berupa pernyataan atau pertanyaan [21].

Berikut merupakan persamaan-persamaan yang dipakai dalam Skala Likert:

1) Hal pertama yang harus dilakukan adalah menentukan skor dari tiap jawaban yang diberikan. Tabel III merupakan skor jawaban dalam penelitian ini.

TABEL III. PENENTUAN SKOR JAWABAN

\begin{tabular}{|c|c|}
\hline Pilihan Jawaban (J) & Bobot Nilai (Bn) \\
\hline Sangat Kurang (SK) & 1 \\
\hline Kurang (K) & 2 \\
\hline Cukup (C) & 3 \\
\hline Baik (B) & 4 \\
\hline Sangat Baik (SB) & 5 \\
\hline
\end{tabular}

2) Setelah ditentukan bobot nilai setiap jawaban, tentukan skor kriteria. Untuk menghitung jumlah skor kriteria dari setiap jawaban digunakan persamaan (1).

$$
\mathrm{Sk}=\mathrm{Bn} \times \mathrm{R}
$$

Keterangan:

Sk $=$ Skor Kriteria 
$\mathrm{Bn} \quad=$ Bobot Nilai

$\mathrm{R}=$ Jumlah Responden

skor kriteria dari tiap jawaban ini dijadikan skala untuk menentukan di nilai berapa setiap pertanyaan dinyatakan sangat kurang, kurang, cukup, baik atau sangat baik.

3) Kemudian dihitung skor tiap jawaban dengan menggunakan persamaan (2).

$$
\mathrm{Sj}=\mathrm{J} \times \mathrm{Bn}
$$

Keterangan:

$$
\begin{array}{ll}
\mathrm{Sj} & =\text { Skor Jawaban } \\
\mathrm{J} & =\text { Pilihan Jawaban } \\
\mathrm{Bn} & =\text { Bobot Nilai }
\end{array}
$$

4) Setelah itu jumlahkan tiap skor jawaban yang ada dengan persamaan (3).

$$
\mathrm{St}=\mathrm{Ssk}+\mathrm{Sk}+\mathrm{Sc}+\mathrm{Sb}+\mathrm{Ssb}
$$

Keterangan:

$\begin{array}{ll}\text { St } & =\text { Skor Total } \\ \text { Ssk } & =\text { Skor Sangat Kurang } \\ \mathrm{Sk} & =\text { Skor Kurang } \\ \mathrm{Sc} & =\text { Skor Cukup } \\ \mathrm{Sb} & =\text { Skor Baik } \\ \mathrm{Ssb} & =\text { Skor Sangat Baik }\end{array}$

5) Selanjutnya untuk mengetahui persentase setiap jawaban yang dijawab oleh responden digunakan persamaan (4) menggunakan jumlah responden.

$$
\mathrm{Pj}=\mathrm{R} / \mathrm{Rt} \times 100 \%
$$

Keterangan:

$$
\begin{array}{ll}
\mathrm{Pj} & =\text { Persentase Jawaban } \\
\mathrm{R} & =\text { Jumlah Responden } \\
\mathrm{Rt} & =\text { Jumlah Responden Total } \\
100 \% & =\text { Bilangan Tetap }
\end{array}
$$

6) Untuk mengetahui persentase total jawaban dari para responden dengan menggunakan persamaan (5).

$$
\mathrm{Pt}=\mathrm{St} / \mathrm{Skt} \times 100 \%
$$

Keterangan:

$$
\begin{array}{ll}
\mathrm{Pt} & =\text { Persentase Total } \\
\mathrm{St} & =\text { Skor Total } \\
\mathrm{Skt} & =\text { Skor Kriteria Tertinggi } \\
100 \% & =\text { Bilangan tetap }
\end{array}
$$

7) Jika masing-masing pertanyaan sudah diketahui skornya maka langkah terakhir adalah mencari rerata skor dari pengujian dengan persamaan (6).

$$
\text { Rerata }=\mathrm{St} 1+\mathrm{St} 2+\mathrm{St} 3+\mathrm{St} 4+\ldots
$$

Keterangan:

St $1=$ Skor Total Pertanyaan 1

St2 $=$ Skor Total Pertanyaan 2

St3 = Skor Total Pertanyaan 3

St $4=$ Skor Total Pertanyaan 4

\section{HASIL DAN PEMBAHASAN}

\section{A. Hasil Perancangan Aplikasi}

1. Tampilan Android di sisi user

Setelah tahap demi tahap proses pembangunan aplikasi pemesanan tiket online ini selesai, sekarang dapat dilihat tampilan yang sudah dibuat baik itu aplikasi yang berbasis Android untuk pengguna dan administrator berbasis web untuk pengelola adminnya.

Gambar 12 adalah Tampilan Muka dari aplikasi Android di smartphone pengguna (user)

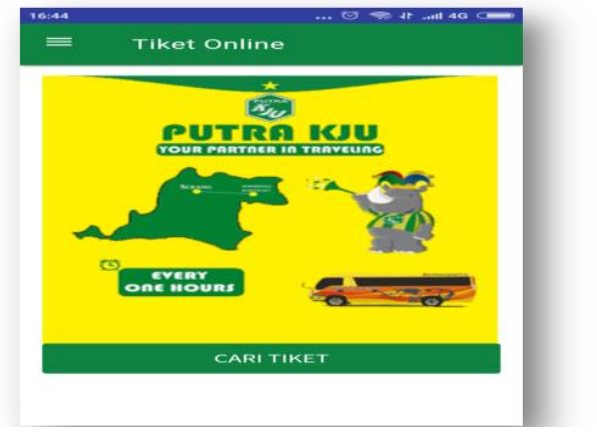

Gambar 12. Tampilan Muka Applikasi Android

Gambar 13 berikut ini adalah tampilan pada aplikasi Android proses pemesanan tiket shuttle bus dan tempat duduk bus (booking seat),

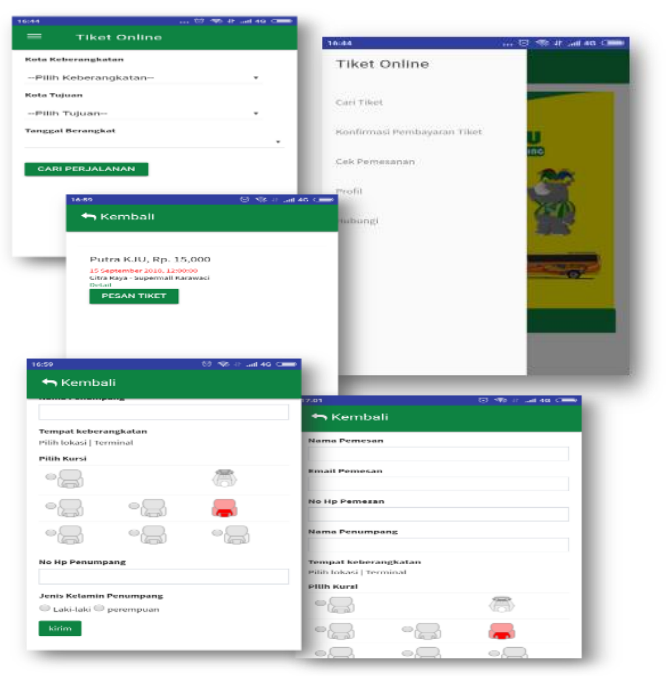

Gambar 13 Tampilan Android di User Ketika Proses Pemesanan Tiket Bus dan Booking Seat Shuttle Bus

Dan berikut ini adalah Gambar 14 tampilan pada aplikasi android Tiket Bus di smartphone user 
yang sudah di konfirmasi pembayaran dan pemesanan duduk bus (booking seat) sudah fixed.

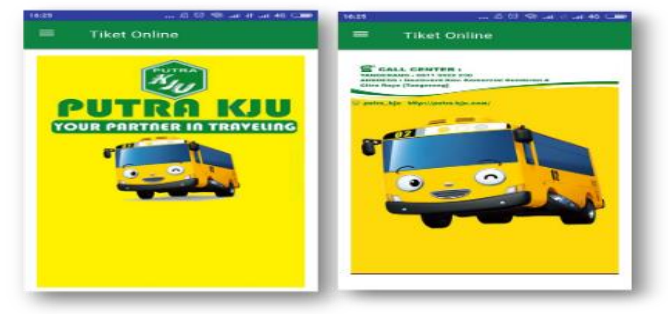

Gambar 14. Tampilan Android di User, Konfirmasi Pembayaran dan Booking Seat

\section{Tampilan di sisi Adminstrator}

a) Tampilan Halaman Login

Tampilan awal dari web administrator adalah form login, yang mengharuskan admin memasukkan user name dan password terlebih dahulu untuk dapat mengakses seluruh halaman web. Gambar 15 menunjukkan halaman login untuk admin

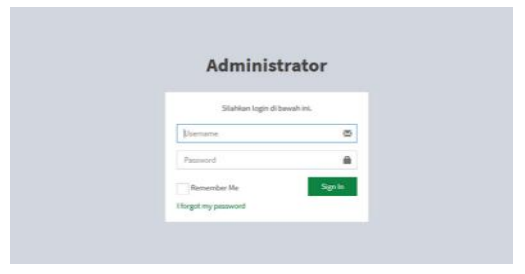

Gambar 15. Tampilan Halaman Login

b) Tampilan Halaman Dashboard

Jika user name dan password yang di-input admin pada halaman login sesuai maka admin bisa langsung masuk ke halaman Dashboard. Admin yang telah berhasil login kemudian masuk ke halaman Dashboard, seperti yang terlihat pada Gambar 16. Admin bisa mengatur semua data tentang aplikasi pemesanan tiket di Putra KJU dengan mеnu mobil/bus yang tersedia, Keberangkatan, Tujuan, Booking seat, Fasilitas, Pemesanan tiket, Konfirmasi pembayaran dan Manajemen user.

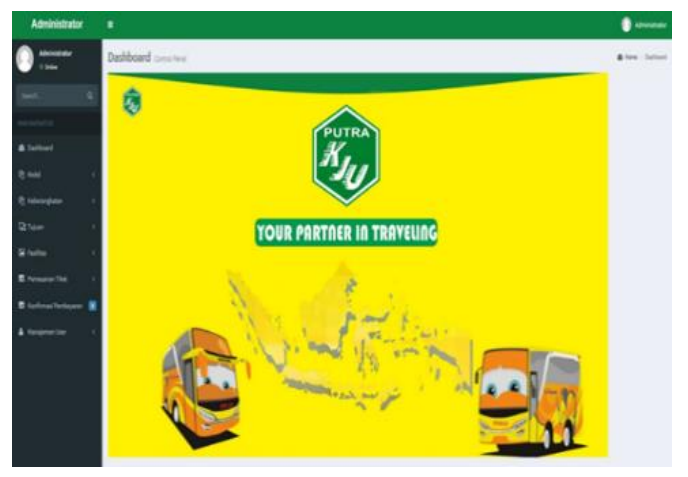

Gambar 16. Tampilan Halaman Dashboard c) Tampilan Halaman Input data user, tujuan, booking dan konfirmasi pembayaran

Tampilan berikut Gambar 17 ini adalah halaman dashboard admin bisa mengatur, menginput, merubah, semua data pemesan (user), booking seat, fasilitas dan semua fungsi yang ada di dalam aplikasi pemesanan tiket di Putra KJU.

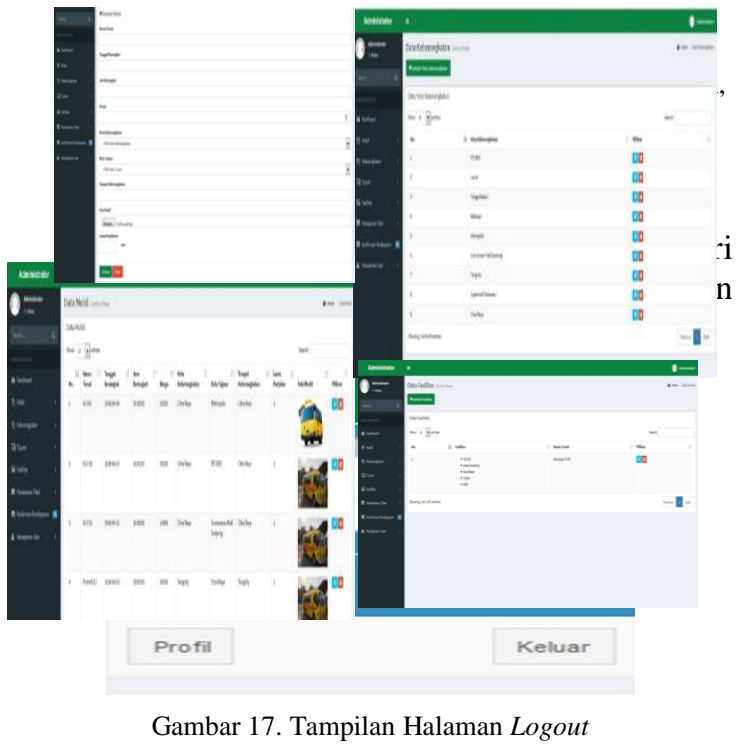

B. Hasil Pengujian Penelitian

1. Deskripsi Pengujian

Setelah melakukan serangkaian tahapan dalam pembuatan aplikasi pemesanan tiket shuttle bus ini, peneliti selanjutnya melakukan pengujian (testing). Pengujian yang dilakukan adalah dengan tiga (3) pengujian, yaitu pengujian Black box, pengujian Alfa dan pengujian Beta dari hasil implemetasi aplikasi pemesanan tiket shuttle bus ini kepada beberapa responden dengan menyebarkan kuesioner

Berikut ini adalah tahapan-tahapan dalam mengimplementasikan aplikasi pemesanan tiket yang telah dibuat pada sisi pemesan (user). Di mana dalam implementasi sistem ini dilakukan di tempat penelitian yaitu pada Perusahaan Putra KJU, adapun tahapan Implementasi adalah sebagai berikut:

a. Tahap pertama yang harus dilakukan adalah membeli hosting dan mengupload system dan database yang telah dibuat untuk dapat diakses semua orang.

b. Mem-build aplikasi pengguna ke dalam bentuk apk untuk kemudian di-upload di layanan google playstore agar dapat di-download oleh para calon penumpang nantinya.

c. Mengedukasi staf loket untuk dapat mengakses halaman administrator yang nantinya akan digunakan untuk menambah jadwal perjalanan, melihat data pemesan dan hal-hal lainnya yang berkaitan dengan halaman admin. 
d. Memberi informasi kepada penumpang yang hendak membeli tiket bahwa untuk pemesanan tiket shuttle bus Putra KJU sudah bisa dilakukan secara online, dan diharapkan calon penumpang dapat men-download aplikasi yang sudah tersedia di playstore.

\section{Pengujian Black Box}

Pada tahap pengujian Black box terhadap aplikasi pemesanan tiket online ini pengujian dilakukan dengan menjalankan semua fungsi dan fitur yang ada dari aplikasi ini dan kemudian dilihat apakah hasil dari fungsi-fungsi tersebut sesuai dengan yang diharapkan, aplikasi dijalankan melalui suatu operating system android untuk user customer dan web browser untuk user admin.

Berikut hasil dari pengujian terhadap aplikasi pemesanan tiket shuttle bus ini dapat dilihat pada Tabel IV dan Tabel V.

\section{TABEL IV. DATA HASIL PENGUJIAN BLACK BOX}

\begin{tabular}{|l|l|l|c|}
\hline Test Case & \multicolumn{1}{|c|}{$\begin{array}{c}\text { Prosedur } \\
\text { Dijalankan }\end{array}$} & \multicolumn{1}{|c|}{$\begin{array}{c}\text { Hasil } \\
\text { Diharapkan }\end{array}$} & $\begin{array}{c}\text { Status } \\
\text { Pengujian }\end{array}$ \\
\hline Start & $\begin{array}{l}\text { User membuka } \\
\text { aplikasi putra KJU }\end{array}$ & $\begin{array}{l}\text { Menampilkan } \\
\text { halaman utama }\end{array}$ & Valid \\
\hline Cari tiket & $\begin{array}{l}\text { User menekan } \\
\text { button cari tiket }\end{array}$ & $\begin{array}{l}\text { Menampilkan } \\
\text { form keberangka } \\
\text { tan, tujuan dan } \\
\text { tanggal berangkat }\end{array}$ & Valid \\
\hline $\begin{array}{l}\text { Cari } \\
\text { perjalanan }\end{array}$ & $\begin{array}{l}\text { User input form } \\
\text { keberangkatan } \\
\text { tujuan dan } \\
\text { tanggal }\end{array}$ & $\begin{array}{l}\text { Menampilkan } \\
\text { jadwal perjalanan }\end{array}$ & Valid \\
\hline Pesan Tiket & $\begin{array}{l}\text { User Input data } \\
\text { pemesan dan pilih } \\
\text { kursi }\end{array}$ & $\begin{array}{l}\text { Menampilkan } \\
\text { pemesanan tiket } \\
\text { berhasil dan } \\
\text { mengirim ke } \\
\text { email pemesan }\end{array}$ & Valid \\
\hline $\begin{array}{l}\text { Menu cek } \\
\text { pemesanan }\end{array}$ & $\begin{array}{l}\text { Menekan menu } \\
\text { dan mengisi form } \\
\text { cek pemesanan }\end{array}$ & $\begin{array}{l}\text { Menampilkan } \\
\text { form pemesanan } \\
\text { dan Data pemesan }\end{array}$ & Valid \\
\hline $\begin{array}{l}\text { Menu } \\
\text { Konfirmasi } \\
\text { Pembayaran }\end{array}$ & $\begin{array}{l}\text { Menekan menu } \\
\text { Konfirmasi } \\
\text { pembayaran dan } \\
\text { mengisi form } \\
\text { konfirmasi }\end{array}$ & $\begin{array}{l}\text { Menampilkan } \\
\text { form konfirmasi } \\
\text { pembayaran dan } \\
\text { menyimpad data } \\
\text { konfirmasi } \\
\text { pembayaran }\end{array}$ & Valid \\
\hline Menu Profil & $\begin{array}{l}\text { Menekan menu } \\
\text { Profil }\end{array}$ & $\begin{array}{l}\text { Menampilkan } \\
\text { menu profil }\end{array}$ & \\
\hline $\begin{array}{l}\text { Menu } \\
\text { Hubungi }\end{array}$ & $\begin{array}{l}\text { Menekan menu } \\
\text { hubungi }\end{array}$ & $\begin{array}{l}\text { Menampilkan } \\
\text { menu hubungi }\end{array}$ & Valid \\
\hline
\end{tabular}

Berdasarkan pengujian Black Box, login dan menu-menu yang dilakukan pada aplikasi dari sisi user ini adalah untuk pengecekan apakah fungsional dari form login telah berjalan dengan baik dan pengujian untuk menu-menu yang dapat diakses user pada aplikasi mobile meliputi menu lihat jadwal, pemesanan, list pemesanan, dan verifikasi pembayaran.

Dari pengujian yang dilakukan didapatkan kesimpulan bahwa form login dan semua menu telah berfungsi dengan baik.
TABEL V. PENGUJIAN BLACK BOX ADMIN

\begin{tabular}{|c|c|c|c|}
\hline Test Case & $\begin{array}{c}\text { Prosedur } \\
\text { dijalankan }\end{array}$ & $\begin{array}{c}\text { Hasil } \\
\text { Diharapkan }\end{array}$ & $\begin{array}{c}\text { Status } \\
\text { Pengujian }\end{array}$ \\
\hline Login & $\begin{array}{l}\text { Admin inputkan } \\
\text { username \& password }\end{array}$ & $\begin{array}{l}\text { Admin masuk } \\
\text { ke dashboard } \\
\text { administrator }\end{array}$ & Valid \\
\hline $\begin{array}{l}\text { Input data } \\
\text { mobil }\end{array}$ & $\begin{array}{l}\text { Pilih menu tambah } \\
\text { mobil, masukan data, } \\
\text { simpan }\end{array}$ & $\begin{array}{l}\text { Data mobil } \\
\text { bertambah }\end{array}$ & Valid \\
\hline $\begin{array}{l}\text { Edit data } \\
\text { mobil }\end{array}$ & $\begin{array}{l}\text { Pilih menu edit,edit data } \\
\text { mobil dan simpan }\end{array}$ & $\begin{array}{l}\text { Data mobil } \\
\text { berubah }\end{array}$ & Valid \\
\hline $\begin{array}{l}\text { Hapus data } \\
\text { mobil }\end{array}$ & $\begin{array}{l}\text { Pilih menu hapus, hapus } \\
\text { data mobil }\end{array}$ & $\begin{array}{l}\text { Data mobil } \\
\text { berkurang }\end{array}$ & Valid \\
\hline $\begin{array}{l}\text { Input data } \\
\text { tujuan }\end{array}$ & $\begin{array}{l}\text { Pilih menu tambah } \\
\text { tujun,masukan data dan } \\
\text { simpan }\end{array}$ & $\begin{array}{l}\text { Data tujuan } \\
\text { bertambah }\end{array}$ & Valid \\
\hline $\begin{array}{l}\text { Edit data } \\
\text { tujuan }\end{array}$ & $\begin{array}{l}\text { Pilih menu edit, } \\
\text { tujuan,edit data tujuan }\end{array}$ & $\begin{array}{l}\text { Data tujuan } \\
\text { berubah }\end{array}$ & Valid \\
\hline $\begin{array}{l}\text { Hapus data } \\
\text { tujuan }\end{array}$ & $\begin{array}{l}\text { Pilih menu hapus } \\
\text { tujuan,hapus data tujuan } \\
\text { dan simpan }\end{array}$ & $\begin{array}{l}\text { Data tujuan } \\
\text { berkurang }\end{array}$ & Valid \\
\hline $\begin{array}{l}\text { Input data } \\
\text { keberangkat } \\
\text { an }\end{array}$ & $\begin{array}{l}\text { Pilih menu tambah } \\
\text { keberangkatan,masukan } \\
\text { data dan simpan }\end{array}$ & $\begin{array}{l}\text { Data } \\
\text { keberangkatan } \\
\text { bertambah }\end{array}$ & Valid \\
\hline $\begin{array}{l}\text { Edit data } \\
\text { keberangkat } \\
\text { an }\end{array}$ & $\begin{array}{l}\text { Pilih menu edit } \\
\text { keberangkatan,edit data } \\
\text { dan simpan }\end{array}$ & $\begin{array}{l}\text { Data } \\
\text { keberangkatan } \\
\text { berubah }\end{array}$ & Valid \\
\hline $\begin{array}{l}\text { Hapus data } \\
\text { keberangkat } \\
\text { an }\end{array}$ & $\begin{array}{l}\text { Pilih menu hapus } \\
\text { keberangkatan,hapus } \\
\text { data dan simpan }\end{array}$ & $\begin{array}{l}\text { Data } \\
\text { keberangkatan } \\
\text { berkurang }\end{array}$ & Valid \\
\hline $\begin{array}{l}\text { Input data } \\
\text { fasilitas }\end{array}$ & $\begin{array}{l}\text { Pilih menu tambah } \\
\text { fasilitas,masukan data } \\
\text { dan simpan }\end{array}$ & $\begin{array}{l}\text { Data fasilitas } \\
\text { bertambah }\end{array}$ & Valid \\
\hline $\begin{array}{l}\text { Edit data } \\
\text { fasilitas }\end{array}$ & $\begin{array}{l}\text { Pilih menu fasilitas,edit } \\
\text { data fasilitas }\end{array}$ & $\begin{array}{l}\text { Data fasilitas } \\
\text { berubah }\end{array}$ & Valid \\
\hline $\begin{array}{l}\text { Hapus data } \\
\text { fasilitas }\end{array}$ & $\begin{array}{l}\text { Pilih menu hapus } \\
\text { fasilitas,hapus data dan } \\
\text { simpan }\end{array}$ & $\begin{array}{l}\text { Data fasilitas } \\
\text { berkurang }\end{array}$ & Valid \\
\hline $\begin{array}{l}\text { Hapus data } \\
\text { pemesan }\end{array}$ & $\begin{array}{l}\text { Pilih menu hapus data } \\
\text { pemesan, konfirmasi } \\
\text { penghapusan }\end{array}$ & $\begin{array}{l}\text { Data pemesan } \\
\text { berkurang }\end{array}$ & Valid \\
\hline $\begin{array}{l}\text { Konfirma si } \\
\text { pembayar an }\end{array}$ & $\begin{array}{l}\text { Pilih menu konfirmasi } \\
\text { pembayaran }\end{array}$ & $\begin{array}{l}\text { Status } \\
\text { pemesanan di } \\
\text { data pemesan } \\
\text { berubah }\end{array}$ & Valid \\
\hline $\begin{array}{l}\text { Input data } \\
\text { User Admin }\end{array}$ & $\begin{array}{l}\text { Pilih menu User } \\
\text { Admin,masukan data } \\
\text { dan simpan }\end{array}$ & $\begin{array}{l}\text { Data User } \\
\text { Admin } \\
\text { bertambah }\end{array}$ & Valid \\
\hline $\begin{array}{l}\text { Edit data } \\
\text { User Admin }\end{array}$ & $\begin{array}{l}\text { Pilih menu User } \\
\text { Admin,edit data dan } \\
\text { simpan }\end{array}$ & $\begin{array}{l}\text { Data User } \\
\text { Admin berubah }\end{array}$ & Valid \\
\hline $\begin{array}{l}\text { Hapus data } \\
\text { User Admin }\end{array}$ & $\begin{array}{l}\text { Pilih menu User } \\
\text { Admin, hapus data dan } \\
\text { simpan }\end{array}$ & $\begin{array}{l}\text { Data User } \\
\text { Admin } \\
\text { berkurang }\end{array}$ & Valid \\
\hline Logout & Pilih menu keluar & $\begin{array}{l}\text { Keluar dari } \\
\text { halaman } \\
\text { administrator }\end{array}$ & Valid \\
\hline
\end{tabular}

Berdasarkan pengujian yang dilakukan untuk menu-menu yang dapat diakses administrator (admin) didapatkan hasil bahwa aplikasi ini sudah berjalan baik secara fungsional dan mengeluarkan informasi sesuai dengan yang diharapkan.

\section{Pengujian Alfa}

Pengujian Alfa dilakukan untuk meninjau apakah aplikasi yang telah dibuat berjalan dengan baik. Dalam pengujian ini dilakukan oleh para ahli perangkat lunak berbasis Web, Php, MySql dan android dengan melihat hasil akhir aplikasi yang telah diaktifkan sebelumnya, sehingga dapat dinilai dari segi fungsi, kegunaan dan penampilan android. Adapun tahapan-tahapan pengujian alfa sebagai berikut:

a. Memberikan link kuesioner online kepada responden alfa.

b. Responden alfa mengupload sistem aplikasi pemesanan tiket shuttle bus di 
layanan google playstore yang telah di hosting database oleh kami.

c. Kemudian para responden alfa memberikan penilaian atau mengisi kuesioner.

\section{Pengujian Beta}

Kelompok pengujian Beta tidak menyertakan orang-orang yang terlibat dalam pembuatan aplikasi. Pada pengujian ini dilakukan dengan cara memberikan tes kuesioner yaitu menjawab kuesioner sesudah menggunakan aplikasi pemesanan tiket shuttle bus. Pengujian ini digunakan untuk mengetahui sejauh mana aplikasi ini berfungsi dengan baik. Pengujian dilakukan dengan cara pembagian kuesioner kepada sampel pengguna (user).

Sampel pngguna (user) berjumlah 27 responden yang berumur 17-30 tahun yang rata-rata dalam sebulan menggunakan jasa transportasi bus sebanyak 1-4 kali. Responden berasal dari berbagai kalangan seperti guru, mahasiswa, siswa, karyawan dan swasta. Berikut ini adalah tahapan-tahapan yang dilakukan oleh responden sebagai berikut:

a. Melakukan implementasi sistem aplikasi pemesanan tiket dengan meng-upload sistem dengan hosting dari kami.

b. Memberikan link kuesioner online kepada responden beta.

c. Responden beta mencoba sistem aplikasi pemesanan tiket yang telah di-upload lalu membuka link kuesioner.

d. Selanjutnya responden beta memberikan penilaian atau mengisi kuesioner.

\section{Data Hasil Pengujian-Pengujian}

\section{Data Hasil Pengujian Alfa}

Pengujian alfa merupakan pengujian program yang dilakukan oleh pembuat aplikasi ataupun orang-orang yang terlibat di dalamnya. Pengujian alfa hanya untuk sirkulasi internal dan masalah (error) atau ketidak lengkapan yang terdapat dalam aplikasi dapat diduga sebelumnya.

\section{Data Hasil Pengujian Beta}

Data pengujian beta adalah berdasarkan hasil pengisian kuesioner para responden yang terdiri dari 27 orang dari berbagai kalangan seperti guru, mahasiwa, siswa karyawan dan swasta. Dengan tujuan untuk melihat sejauh mana kegunaan dan kemanfaatan aplikasi ini bagi para para pengguna (user) khususnya dan masyarakat pada umumnya.
TABEL VI. DATA HASIL PENGUJIAN ALFA

\begin{tabular}{|c|c|c|c|c|c|c|}
\hline \multirow[b]{2}{*}{ No } & \multirow[b]{2}{*}{ Pertanyaan } & \multicolumn{5}{|c|}{ Pilihan Jawaban } \\
\hline & & 1 & 2 & 3 & 4 & 5 \\
\hline 1 & $\begin{array}{l}\text { Apakah aplikasi ini } \\
\text { menarik dari segi } \\
\text { grafis/desain? }\end{array}$ & - & - & 1 & 2 & 6 \\
\hline 2 & $\begin{array}{l}\text { Apakah aplikasi ini } \\
\text { menarik dari segi } \\
\text { animasi dan warna? }\end{array}$ & - & - & & 4 & 5 \\
\hline 3 & $\begin{array}{l}\text { Apakah aplikasi ini } \\
\text { jelas (tesk) dan tidak } \\
\text { membingungkan? }\end{array}$ & - & - & 2 & 5 & 2 \\
\hline 4 & $\begin{array}{l}\text { Apakah aplikasi ini } \\
\text { mudah untuk dipelajari } \\
\& \text { diingat? }\end{array}$ & - & - & 3 & 2 & 4 \\
\hline 5 & $\begin{array}{l}\text { Apakah semua menu } \\
\text { pada aplikasi ini dapat } \\
\text { berfungsi dengan } \\
\text { baik? }\end{array}$ & - & - & - & 2 & 7 \\
\hline 6 & $\begin{array}{l}\text { Apakah semua menu } \\
\text { pada aplikasi ini } \\
\text { berguna dalam proses } \\
\text { pemesanan tiket? }\end{array}$ & - & - & - & 3 & 6 \\
\hline 7 & $\begin{array}{l}\text { Apakah aplikasi ini } \\
\text { termasuk kategori } \\
\text { inovatif \& interaktif }\end{array}$ & - & - & 2 & 3 & 4 \\
\hline
\end{tabular}

Keterangan: 5 : Sangat Baik, 4 : Baik, 3 : Cukup Baik, 2 : Kurang Baik, 1 : Sangat Kurang Baik

TABEL VII. DATA HASIL PENGUJIAN BETA

\begin{tabular}{|c|c|c|c|c|c|c|}
\hline \multirow{2}{*}{ No } & \multirow{2}{*}{ Pertanyaan } & \multicolumn{5}{|c|}{ Pilihan Jawaban } \\
\hline & & 1 & 2 & 3 & 4 & 5 \\
\hline 1 & $\begin{array}{l}\text { Apakah pemesanan tiket } \\
\text { lebih cepat dengan aplikasi } \\
\text { online? }\end{array}$ & - & - & 3 & 6 & 18 \\
\hline 2 & $\begin{array}{l}\text { Apakah ketika transaksi } \\
\text { pemesanan tiket dengan } \\
\text { aplikasi ini lebih mudah? }\end{array}$ & - & - & 2 & 5 & 17 \\
\hline 3 & $\begin{array}{l}\text { Apakah nyaman dan paham } \\
\text { pemesanan tiket dengan } \\
\text { applikasi online? }\end{array}$ & - & - & 4 & 7 & 16 \\
\hline 4 & $\begin{array}{l}\text { Apakah dengan sosialisasi } \\
\text { pemesanan tiket aplikasi } \\
\text { online ini mampu mengajak } \\
\text { masyarakat untuk menaiki } \\
\text { bus di Putra KJU? }\end{array}$ & - & - & 1 & 6 & 20 \\
\hline 5 & $\begin{array}{l}\text { Apakah anda lebih suka } \\
\text { pembayaran tiket bus ini } \\
\text { dengan melalui aplikasi } \\
\text { (transfer)? }\end{array}$ & - & - & 1 & 7 & 19 \\
\hline 6 & $\begin{array}{l}\text { Apakah semua menu yang } \\
\text { ada di aplikasi ini sudah } \\
\text { lengkap? }\end{array}$ & - & - & 4 & 5 & 18 \\
\hline 7 & $\begin{array}{l}\text { Apakah aplikasi ini termasuk } \\
\text { inovatif/ canggih? }\end{array}$ & - & - & 3 & 2 & 22 \\
\hline
\end{tabular}

Kurang Baik, 1 : Sangat Kurang Baik 


\section{Analisa Hasil Pengujian-Pengujian}

1. Analisis Data Pengujian Alfa

Analisis data dalam pengujian alfa, dihitung berdasarkan masing-masing poin dari setiap pertanyaan dengan menggunakan Skala Likert. Responden alfa ini sebanyak 9 orang. Adapun Skor Kriteria pada Tabel VIII dan Data Hasil Skor Pengujian Alfa pada Tabel IX. Serta grafik persentase keberhasilan pengujian Alfa pada Gambar 18 berikut ini:

TABEL VIII. SKOR KRITERIA PENGUJIAN ALFA

\begin{tabular}{|c|c|c|}
\hline No & Kategori & Rentang Nilai \\
\hline 1 & Sangat baik & $36,1-45,0$ \\
\hline 2 & Baik & $27,1-36,0$ \\
\hline 3 & Cukup baik & $18,1-27,0$ \\
\hline 4 & Kurang baik & $9,1-18,0$ \\
\hline 5 & Sangat kurang baik & $00,0-9,0$ \\
\hline
\end{tabular}

TABEL IX. DATA HASIL SKOR PENGUJIAN ALFA

\begin{tabular}{|c|c|c|c|}
\hline No & Pernyataan & $\begin{array}{l}\text { Perolehan } \\
\text { Nilai }\end{array}$ & $\begin{array}{c}\text { Persentase } \\
\text { Keberhasilan }\end{array}$ \\
\hline 1 & $\begin{array}{l}\text { Apakah aplikasi ini } \\
\text { menarik dari segi } \\
\text { grafis /desain? }\end{array}$ & 41 & $91,1 \%$ \\
\hline 2 & $\begin{array}{l}\text { Apakah aplikasi ini } \\
\text { menarik dari segi } \\
\text { animasi dan warna? }\end{array}$ & 41 & $91,1 \%$ \\
\hline 3 & $\begin{array}{l}\text { Apakah aplikasi ini } \\
\text { jelas (tesk) dan tidak } \\
\text { membingungkan? }\end{array}$ & 36 & $80 \%$ \\
\hline 4 & $\begin{array}{l}\text { Apakah aplikasi ini } \\
\text { mudah untuk } \\
\text { dipelajari \& diingat? }\end{array}$ & 37 & $82,2 \%$ \\
\hline 5 & $\begin{array}{l}\text { Apakah semua menu } \\
\text { pada aplikasi ini } \\
\text { dapat berfungsi } \\
\text { dengan baik? }\end{array}$ & 43 & $95,5 \%$ \\
\hline 6 & $\begin{array}{l}\text { Apakah semua } \\
\text { menu pada aplikasi } \\
\text { ini berguna dalam } \\
\text { proses pemesanan } \\
\text { tiket? }\end{array}$ & 42 & $93,3 \%$ \\
\hline 7 & $\begin{array}{l}\text { Apakah aplikasi ini } \\
\text { termasuk kategori } \\
\text { inovatif \& interaktif? }\end{array}$ & 38 & $84,4 \%$ \\
\hline
\end{tabular}

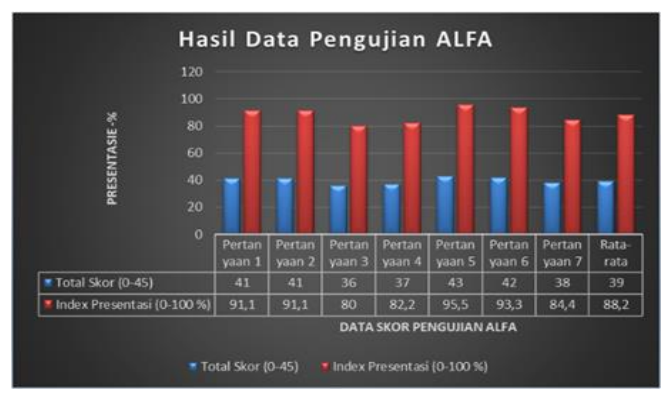

Gambar 18. Grafik Persentase Keberhasilan Pengujian Alfa
2. Analisis Data Pengujian Beta

Sama seperti pengujian alfa, dalam pengujian beta juga dihitung berdasarkan masing-masing poin dari setiap pertanyaan dengan menggunakan Skala Likert. Responden beta ini sebanyak 27 orang. Adapun skor kriteria pengujian Beta pada Tabel X dan data hasil skor pengujian Beta pada Tabel XI. Serta grafik persentase keberhasilannya pengujian Beta pada Gambar 19.

TABEL X. SKOR KRITERIA PENGUJIAN BETA

\begin{tabular}{|c|c|c|}
\hline No & Kategori & Rentang Nilai \\
\hline 1 & Sangat baik & $108,1-135,0$ \\
\hline 2 & Baik & $81,1-108,0$ \\
\hline 3 & Cukup baik & $54,1-81,0$ \\
\hline 4 & Kurang baik & $27,1-54,0$ \\
\hline 5 & Sangat kurang baik & $00,0-27,0$ \\
\hline
\end{tabular}

TABEL XI. DATA HASIL SKOR PENGUJIAN BETA

\begin{tabular}{|c|c|c|c|}
\hline No & Pernyataan & $\begin{array}{l}\text { Perolehan } \\
\text { Nilai }\end{array}$ & $\begin{array}{c}\text { Persentase } \\
\text { Keberhasilan }\end{array}$ \\
\hline 1 & $\begin{array}{l}\text { Apakah pemesanan } \\
\text { tiket lebih cepat } \\
\text { dengan aplikasi } \\
\text { online? }\end{array}$ & 123 & $91,1 \%$ \\
\hline 2 & $\begin{array}{l}\text { Apakah ketika } \\
\text { transaksi pemesanan } \\
\text { tiket dengan aplikasi } \\
\text { ini lebih mudah? }\end{array}$ & 118 & $87,4 \%$ \\
\hline 3 & $\begin{array}{l}\text { Apakah nyaman dan } \\
\text { paham pemesanan } \\
\text { tiket dengan } \\
\text { applikasi online? }\end{array}$ & 120 & $88,9 \%$ \\
\hline 4 & $\begin{array}{l}\text { Apakah dengan } \\
\text { sosialisasi pemesanan } \\
\text { tiket aplikasi online } \\
\text { ini mampu mengajak } \\
\text { masyarakat untuk } \\
\text { menaiki bus di Putra } \\
\text { KJU? }\end{array}$ & 127 & $94,1 \%$ \\
\hline 5 & $\begin{array}{l}\text { Apakah anda lebih } \\
\text { suka pembayaran tiket } \\
\text { bus ini dengan melalui } \\
\text { aplikasi (transfer) }\end{array}$ & 126 & $93,3 \%$ \\
\hline 6 & $\begin{array}{l}\text { Apakah semua } \\
\text { menu yang ada di } \\
\text { aplikasi ini sudah } \\
\text { lengkap? }\end{array}$ & 122 & $90,4 \%$ \\
\hline 7 & $\begin{array}{l}\text { Apakah aplikasi ini } \\
\text { termasuk inovatif/ } \\
\text { canggih? }\end{array}$ & 127 & $94,1 \%$ \\
\hline
\end{tabular}




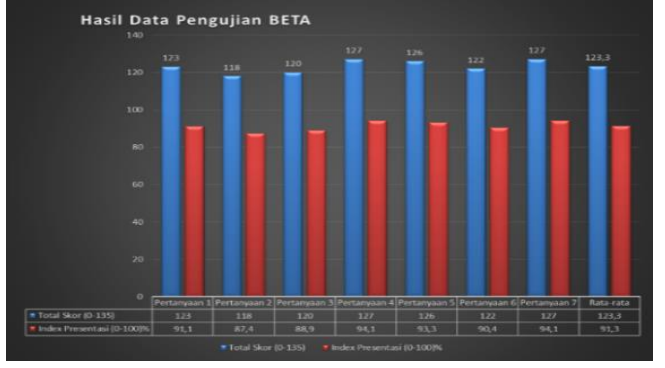

Gambar 19. Grafik Persentase Keberhasilan Pengujian Beta

\section{KESIMPULAN DAN SARAN}

\section{A. Kesimpulan}

Berdasarkan hasil penelitian, perancangan dan pengujian yang telah dilakukan pada aplikasi pemesanan tiket shuttle bus Putra KJU dengan tahapan proses yang telah dilaksanakan mulai dari perencanaan, analisis, design, coding, implementasi dan pengujian. Berdasarkan hasil pengujian dan data kuesioner dengan metode pengujian Black box, pengujian Alfa dan pengujian Beta, maka penulis menarik kesimpulan sebagai berikut [22]:

1. Dengan kemajuan pada teknologi informasi saat ini yaitu sistem Android, yang dalam penelitian ini penulis mengunakan sistem Android Studio yang diintegrasikan dengan sistem Framework Code Igniter untuk merancang aplikasi pemesanan tiket shuttle bus Putra KJU, dimana terbukti aplikasi pemesanan tiket shuttle bus Putra KJU berjalan dengan baik. Dan terbukti bahwa aplikasi yang dirancang dengan berbasis Android Studio dapat compatible dengan baik ketika diintegrasikan dengan sistem framework code igniter pada sistem mobile.

2. Aplikasi Android Studio yang diintegrasikan framework CodeIgniter dengan tampilan yang sederahana dan user input yang tidak rumit dapat digunakan dalam melakukan pemesanan tiket secara mobile. Di mana hal ini sangat membantu user menghemat waktu, biaya dan tenaga karena memesan tiket dan booking seat secara langsung, mengetahui jadwal, jumlah tiket tersisa, keberangkatan dan tujuan user, semua bisa dilakukan dan diinformasikan melalui smartphone mereka. Semua hal ini sangat membantu aktifitas user menjadi lebih efektif dan efisiensi dalam waktu mereka.

3. Pada pengujian black box, digunakan untuk menguji fungsionalitas aplikasi. Hasil pengujian black box menunjukkan bahwa semua fungsionalitas pada aplikasi telah berjalan dengan baik sesuai dengan perencanaan dan perancangan aplikasi pemesanan tiket yamg melalui sistem berbasis
Android secara online.

4. Hasil pengujian Alfa menyatakan bahwa aplikasi pemesanan tiket shuttle bus berbasis android ini mempunyai nilai akhir dengan ratarata sebesar 39 berada di kategori "sangat baik" dan mempunyai persentase keberhasilan mencapai $\mathbf{8 8 , 2 \%}$. Maka aplikasi pemesanan tiket shuttle bus ini layak secara fungsional untuk digunakan bagi perusahaan ataupun vendor transportasi.

5. Hasil pengujian Beta menyatakan bahwa aplikasi pemesanan tiket shuttle bus ini mempunyai nilai akhir dengan rata-rata sebesar 123,3 berada di kategori "sangat baik" dan mempunyai persentase keberhasilan mencapai 91,3\%. Maka aplikasi pemesanan tiket shuttle bus ini layak digunakan untuk sistem pemesanan tiket shuttle bus pada masyarakat pengguna transportasi.

B. Saran

Penulis menyadari bahwa aplikasi pemesanan tiket berbasis Android masih banyak kekurangan dan jauh dari kesempurnaan. Karenanya penulis memberikan saran sebagai berikut:

1. Dalam pengembangan pembuatan aplikasi pemesanan tiket shuttle bus ini berikutnya sebaiknya lebih dilengkapkan fungsinya ditambahkan lama menunggu bus dan dalam transaksi pemesanan tiket bisa langsung dengan pihak bank (E-Commerce).

2. Diharapkan di masa yang akan datang bisa lebih dikembangkan kegunaannya dan lebih lebih luas jangkauan pemesannya (user) yang bisa menggunakannya.

\section{REFERENSI}

[1] J.M. Rabaey. The human Intranet-Where Swarms and Humans Meet. IEEE Pervasive Computing.2015;14(1): 78-83. Doi: 10.1109/MPRV.2015.20

[2] S.Kazi, M.Bagasrawala, F.Shaikh, A.Sayyed. Smart Eticketing System for Public Transport Bus. IEEE International Conference on Smart City and Emerging Technology (ICSCET). Mumbai, 2018 ;1-7. Doi:10.1109/ ICSCET.2018.8537302

[3] L.Allison, M.M.Fuad. Inter-App communication between Android Apps developed in App-Inventor and Android Studio. IEEE ACM International Conference on mobile Software Engineering and System (MobileSoft). Austin. 2016: 17-18. Doi: 10.1109/MobileSoft.2016.018

[4] DestiningrumM, Adrian,Q Javar.Sistem Informasi Penjadwalan Dokter berbasis web dengan menggunakan Framework CodeIgniter (Studi kasus: Rumh sakit Yukum Medical Centre). Jurnal Teknoinfo, 2017;11(2):30-37. Http://ejurnal.teknokrat.ac.id/index. php teknoinfo/article/view/24

[5] A I Ramdhani,S Khasanah,R Farizki. Sistem aplikasi pemesanan tiket bus berbasis website pada PO Sinar Jaya.Syntax Idea.September 2020;2(9). P-ISSN:26846853, e-ISSN:2684-883 
[6] M Yusuf,Daruri,Jaroji. Aplikasi penjualan tiket Ro-Ro Bengkali berbasis android. Jurnal Inovtek Polbeng-Seri Informatika.2019:4(2). ISSN :2527-9866

[7] Cindy Klaudya Putri,Dwiny Desti Meidelfi, Aldo Erianda.Perancangan Aplikasi Pemesanan Travel Antar Kota di Sumatera Barat Berbasis Android. Jurnal of Applied Computer Science and Technology,Juni 2020 :1(1):32-37.

[8] W. Infana, A. Nugraha, M.Awaludin. Pembuatan Aplikasi Peta Rute Bus Rapid Transit (BRT) kota Semarang berbasis mobile GIS menggunakan smartphone Android. Jurnal Geodesi Undip,Jan 2019:8(1):228-237.

[9] X.Meng,K.Qian,D.Lo,H.Shahriar,MDA.Talukder,P.Bra ttacharya. Secure Mobile IPC Software development with Vulnerability Detectorsin Android Studio.IEEE $2018,42^{\text {nd }}$ Annual Computer Software and Applications Conference (COMPSAC). Tokyo.2018:829-830. Doi:10. 1109/COMPSAC.2018.00141

[10] Bryan Bryan, Manurung Jhon Edwin, Nasution Ramadani. Sistem Pemesanan Tike tBus Online pada Bandara Udara di Medan berbasisi Android. Jurnal Teknik Informasi dan Komputer (Tekinkom), Juli 2019:2(1):99-104.ISSN:2621-3079. Doi: https://doi.org /10.37600/Tekinkom.v2i1.94

[11] Seng Hansun, Marcel B.Kristanda, Michael W Saputra. Pemrograman Android dengan Android Studio IDE. ISBN 9789792960945(Andi Publisher). 2016.

[12] Alfa Satyaputra Eva M Aritonang. Let's Build Your Android Apps with Android Studio. ISBN 9786020297590 (Elex Media Komputindo).2016

[13] M.Kong, M.Li, T.Tang, KTian, LMoreira-Matias, F Xia. Shared Subway Shuttle Bus Route Planning Based on Transport Data Analytics. In IEEE, Transactions on Automation Science and Engineering, October 2018. 15(4):1507-1520.Doi:10.1109/TASE.2018.2865494

[14] A.Gunawan. Selection of Web-Based Framework for System Development using AHP (Analytic Hierarchy Process) Method in PT.XYZ. International Conference on Information Management and Technology (ICIMTech). Bandung. 2020:148-152. Doi:10.1109/ ICIMTech50083.2020.9211112

[15] Budi Raharjo. Belajar Otodidak Framework Code Igniter+ CD Edisi Revisi.ISBN 9786026232618 (Informatika).2018

[16] Baibul Tujni,Hutrianto.Pengembangan Perangkat Lunak Monitoring Wellies dengan metode Waterfall Model. Jurnal Ilmiah.2020.22(1). Doi:https://doi.org/ 10.33557/jurnalmatrik.v22i1.862

[17] D.I. Scarisoreanu. Configuring and application which allows online booking and purchase of travel tickets for railway and road transport-Unified Modeling Language. IEEE International Conference on Mathematics and Computers in Science and Engineering (MACISE). Madrid. 2020: 30-33. Doi: 10.1109/MACISE49704.2020.00013

[18] R Guidotti, A Monneale, F Giannotti, D Pedreschi, S Ruggieri,F Turini. Factual and Counterfactual Explanations for Black Box Decision Making. IEEE Intelligent Systems. 1Nov-Dec 2019; 34(6) :14-23. Doi:10.1109/MIS.2019. 2957223

[19] L Seabra. Alfa Detector Control System. IEEE International Conference on Industrial Technology (ICIT).Seville.2015:93-98.Doi:10.1109/ICIT.2015.7125 082

[20] Baslie Zimmermmam. Beta testing the Framework, Science dan Technology Studies. In Waves and Forms:Electronic Music Devices and Computer Encoding in China. MITPress. 2015:185-197.Online ISBN: 9780262328159

[21] H.Hornbeck, U Alim. UofC-Bayes: A Bayesian Approach to Visualizing Uncertainty in Likert Scales. IEEE International Conference on Visual Analytics
Science and Technology (VAST)..Vancouver.2019:130131.Doi:10.1109/VAST47406.2019.8986935

[22] D R R Herlein, C A Talay, C N Gonzalez, F A Trinidad, L A Marrone. Performance of TCP Vegas According to Alfa and Beta Parameters in Hybrid Scenario's with Bursts Errors. International Conference on Information Systems and Computer Science (INCISCOS), Quito. 2017:217-223.Doi: 10.1109/INCISCOS.2017.16 